\title{
MOTEKAR (Motivator Ketahanan Keluarga) dan Pemberdayaan Keluarga Rentan
}

\author{
Viena Rusmiati Hasanah ${ }^{1)}$, Dede Nurul Komariah' ${ }^{2)}$ \\ ${ }^{1)}$ Universitas Pendidikan Indonesia, Bandung \\ ${ }^{2}$ Universitas Siliwangi, Tasikmalaya \\ Email:viena@upi.edu
}

\begin{abstract}
Abstrak
Permasalahan kerentanan keluarga telah lama menjadi isu nasional yang penanganannya memerlukan kerja sama yang serius antara keluarga, masyarakat dan pemerintah. Berbagai upaya penanganan permasalahan kerentanan keluarga telah banyak dilakukan, namun penanganannya hanya dilakukan pada ranting permasalahan belum pada akar permasalahan. MOTEKAR adalah agen yang dibentuk oleh pemerintah daerah Jawa barat melalui DP3AKB (Dinas Pemberdayaan Perempuan Perlindungan Anak dan Keluarga Berencana) untuk melakukan program pendampingan dan pemberdayaan keluarga. Penelitian ini bertujuan untuk mendeskripsikan peran dan fungsi MOTEKAR yang dilaksanakan di masyarakat pada keluarga rentan perkotaan serta kendala yang dihadapi, khususnya di wilayah Kecamatan Babakan Sari Kota Bandung. Penelitian ini menggunakan pendekatan kualitatif dengan metode deskriptif. Pengumpulan data menggunakan teknik observasi partisipatif, wawancara mendalam, dan studi dokumentasi. Hasil penelitian menunjukkan bahwa dalam mendukung ketahanan keluarga, MOTEKAR melaksanakan fungsi motivator, fasilitator, inovator, dan dinamisator serta melakukan tugas mulai dari mengidentifikasi masalah, memberikan motivasi, memediasi, mendidik, merencanakan solusi, serta mengadvokasi keluarga rentan. Dukungan dan komitmen berbagai pihak terkait dalam penyelesaian masalah dan pengembangan program pembangunan ketahanan keluarga sangat dibutuhkan MOTEKAR dalam menyelesaikan tugasnya di lapangan.
\end{abstract}

Kata Kunci: Pemberdayaan keluarga rentan, Ketahanan keluarga, Motivator

\section{MOTEKAR (Family Resilience Motivator) and Empowerment of Vulnerable Family}

\begin{abstract}
The problem of family vulnerability has long been a national issue which requires serious cooperation between families, communities and the government. Many efforts to deal with family vulnerability problems have been carried out, but the handling is only done on the branches of the problem not at the root of the problem. MOTEKAR is an agent formed by the West Java regional government through DP3AKB (Women's Empowerment and Family Planning Empowerment Service) to conduct family assistance and empowerment programs. This study aims to describe the roles and functions of
\end{abstract}


MOTEKAR implemented in communities in vulnerable urban families and the obstacles faced, especially in the Babakan Sari District of Bandung City. This study uses a qualitative approach with descriptive methods. Data collection uses participatory observation techniques, in-depth interviews, and documentation studies. The results showed that in supporting family resilience, MOTEKAR carried out the functions of motivators, facilitators, innovators, and dynamists and carried out tasks ranging from identifying problems, motivating, mediating, educating, planning solutions, and advocating for vulnerable families. The support and commitment of various parties involved in problem solving and the development of family resilience development programs are very much needed by MOTEKAR in completing its tasks in the field.

\section{Key Words: [Empowerment of Vulnerable family, Family Resilience, Motivator]}

\section{PENDAHULUAN}

Kerentanan keluarga merupakan ketidakmampuan keluarga dalam merespon situasi krisis/konflik/darurat (Sunarti, 2014, hlm. 35). Kerentanan keluarga berkaitan erat dengan bagaimana keluarga dapat menghadapi berbagai ancaman atau gangguan yang dapat menganggu kestabilan dan kesejahteraan keluarga. Beberapa hal kondisi yang menjadi pemicu kerentanan keluarga diantaranya karena faktor ekonomi, sosial budaya dan psikologis, seperti akibat tidak memiliki pekerjaan dan penghasilan yang cukup, gizi buruk dan penyakit, ketidakbijakan dalam menggunakan teknologi, kurangnya pendidikan dan keterampilan, perceraian dan ketidakharmonisan dalam keluarga, pola asuh dan kasus kekerasan kepada anak, gaya hidup dan pergaulan yang materialistis, kurangnya pemahaman agama dan religi dan berbagai kondisi lain yang dapat mengancam ketahanan dan kesejahteraan keluarga.

Studi terdahulu mengungkapkan bahwa masyarakat miskin cenderung tidak berpartisipasi dalam kegiatan sosial dan kegiatan politik (Blum, 1964, hlm. 195-207; Matthews, 1954; Wright
\& Hyman, 1958 hlm.284-294), memiliki aspirasi rendah (Alix \& Lautz, 1973, hlm. 596-607; Smith \& Morgan, 1970, hlm. 286-295), dan cenderung memiliki kesejahteraan psikologis dan kepuasan hidup yang rendah (Langer, 1963). Selain itu Gitmez, et al. (1995) melaporkan bahwa ada 3 tipe orang miskin yaitu: 1) orang-orang dengan pendapatan yang relatif lebih tinggi dan memiliki motivasi psikologis dan perlengkapan yang lebih baik, misalnya pada tipe masyarakat ini mereka memprioritaskan tingkat pendidikan yang lebih tinggi dengan harapan bahwa pendidikan dapat menarik diri mereka keluar dari kemiskinan; 2) orang-orang yang memiliki pendapatan rendah, kurangnya minat pada pendidikan, tidak memiliki motivasi untuk keluar dari kemiskinan, akan tetapi mereka mencoba untuk mengatasi kemiskinannya; 3) orang-orang yang memiliki jumlah pendapatan dan pendidikan yang paling sedikit, tidak memiliki banyak kendali atas kehidupan mereka, tidak memiliki motivasi untuk melepaskan diri dari kemiskinan, dan mereka juga tidak memiliki kemampuan 
untuk menyesuaikan diri dengan kehidupan yang stabil di bawah kondisi kekurangan ekonomi. Oleh karena itu masyarakat miskin perkotaan ada dalam kondisi ketidakberdayaan yang kompleks dan membutuhkan upaya membangun "power"/kekuatan untuk bangkit dari keterpurukan.

Sunarti (2017, hlm. 11-14) mengungkapkan bahwa ketahanan keluarga merupakan kemampuan keluarga dalam mengelola masalah yang dihadapi berdasarkan sumberdaya yang dimiliki untuk memenuhi kebutuhan keluarganya. Adapun indikator umum ketahanan keluarga dibagi kedalam tiga aspek yaitu ketahanan fisik-ekonomi, ketahanan psikologis, dan ketahanan sosial.

a. Ketahanan fisik-ekonomi berkaitan dengan kemampuan ekonomi keluarga yang merupakan kemampuan anggota keluarga dalam memperoleh sumberdaya ekonomi dari luar sistem keluarga guna memenuhi kebutuhan dasar seperti sandang, pangan, perumahan, pendidikan, dan kesehatan. Keluarga dapat dikatakan telah memiliki ketahanan apabila pendapatan perkapita melebihi kebutuhan fisik minimum (sandang, pangan, papan) dan atau lebih dari satu orang bekerja dan memperoleh sumberdaya ekonomi melebihi kebutuhan fisik dan kebutuhan perkembangan seluruh anggota keluarga.

b. Ketahanan sosial berkaitan dengan kekuatan keluarga dalam menerapkan nilai agama, pemeliharaan ikatan dan komitmen, komunikasi efektif, pembagian dan penerimaan peran, penetapan tujuan, serta dorongan untuk maju yang akan menjadi kekuatan dalam menghadapi masalah keluarga serta memiliki hubungan sosial yang positif. Ketahanan sosial terdiri dari sumberdaya non-fisik, mekanisme penganggulangan masalah yang baik, berorientasi pada nilai-nilai agama, efektif dalam berkomunikasi, senantiasa memelihara hubungan sosial, serta memiliki penanggulangan krisis atau masalah.

c. Ketahanan psikologis merupakan kemampuan anggota keluarga untuk mengelola emosinya sehingga menghasilkan konsep diri yang positif, kekuatan, kepuasan terhadap pemenuhan kebutuhan dan pencapaian tugas perkembangan keluarga. Kemampuan mengelola emosi dan konsep diri yang baik menjadi kunci dalam menghadapi masalah-masalah keluarga yang bersifat non-fisik (atau masalah yang tidak berkaitan dengan materi seperti masalah kesalahpahaman, konflik suami dan istri, dsb). Keluarga dikatakan memiliki ketahanan psikologis apabila anggota keluarga memiliki konsep diri dan emosi yang positif. Syarat utama untuk tercapainya ketahanan psikologis adalah kepribadian yang matang dan kecerdasan emosi pasangan suami dan istri.

Perhatian pemerintah dalam pembangunan keluarga, dicanangkan melalui Undang Undang Nomor 52 Tahun 2009 Tentang Kependudukan dan Pembangunan Keluarga. Pada awalnya undang-undang ini fokus pada 
pembangunan kesejahteraan keluarga yang berkaitan dengan output keluarga baik dimensi kesejahteraan fisik (physical well-being), kesejahteraan sosial (social well-being), kesejahteraan ekonomi (economical well-being), maupun kesejahteraan psikologispiritual (psychological-spiritual wellbeing). Selanjutnya Peraturan Menteri Pemberdayaan Perempuan dan Perlindungan Anak Nomor 6 Tahun 2013 Tentang Pelaksanaan Pembangunan Ketahanan Keluarga pasal 11 disebutkan bahwa pembangunan keluarga dapat dilakukan melalui pemberdayaan keluarga rentan dengan memberikan perlindungan dan bantuan untuk mengembangkan dirinya dan keluarganya.

Mengacu dari Undang Undang dan Peraturan Pemerintah tersebut, pada tahun 2014, pemerintah Jawa Barat mengesahkan PERDA JABAR Nomor 9 tahun 2014 tentang penyelenggaraan Pembangunan Ketahanan Keluarga. Sebagai amanah PERDA tersebut, dibentuk MOTEKAR yang merupakan kader pemberdayaan masyarakat yang berasal dari masyarakat desa/kelurahan setempat, yang memiliki pengetahuan, kemauan, dan kemampuan untuk memfasilitasi kegiatan pemberdayaan keluarga pra-sejahtera dan perempuan dalam meningkatkan kualitas hidupnya dan keluarganya agar lebih baik.

Tujuan dibentuknya program ini pada dasarnya adalah untuk memberikan edukasi kepada masyarakat mengenai pentingnya suatu ketahanan keluarga sehingga pada akhirnya diharapkan terciptanya keluarga sejahtera dan berkualitas. Ketahanan keluarga merupakan salah satu ujung tombak pembangunan suatu bangsa di masa depan, maka dari itu tingkat ketahanan keluarga akan sangat berpengaruh terhadap kualitas pembangunan.

Keluarga merupakan unit terkecil masyarakat yang mengalami perubahanperubahan baik secara internal (dari dalam kelurga) maupun eksternal (dari luar keluarga). Perubahan secara internal misalnya pertambahan jumlah anggota keluarga, bertambahnya usia setiap anggota keluarga, jenjang pendidikan anak yang semakin meningkat, dll. Sedangkan perubahan secara eksternal misalnya perubahan teknologi, perubahan sosial masyarakat, gaya hidup, kebijakan pemerintah, dll. Seperti yang diungkapkan oleh Dorothy (2013, hlm. 119) yang menyebutkan bahwa:

"Families are constantly faced with multiple challenges (e.g., divorce, violence, economic hardship, mental and physical illnesses, immigration, who that impact not only individual family members but also the family system as a unit. (Keluarga terus dihadapkan dengan berbagai tantangan misalnya perceraian, kekerasan, kesulitan ekonomi, penyakit mental dan fisik, hingga imigrasi, yang berdampak tidak hanya bagi anggota keluarga individu, tetapi juga sistem keluarga sebagai satu kesatuan. Sifat dinamis dari fungsi keluarga juga berdampak pada perkembangan ketahanan)."

MOTEKAR dalam proses pemberdayaan keluarga rentan berfungsi sebagai pemberdaya yang pada dirinya memiliki kemampuan berupa aspek kognitif, afektif, dan psikomotorik dari pengetahuan dan pengalaman hidupnya 
sehingga mampu memberikan motivasi mengenai nilai-nilai keberdayaan keluarga pada warga sasarannya. Pemberdayaan masyarakat pada umumnya dimulai dari adanya inisiasi dan stimulasi dari orang lain yang memiliki keberdayaan dalam dirinya dan mampu untuk mentransformasikan nilainilai keberdayaan kepada keluarga yang mengalami ketidakberdayaan diri (BP3AKB, 2014, hlm. 20). Maka dari itu peran MOTEKAR sangat dibutuhkan dalam upaya memberdayakan masyarakat.

Dalam konteks itulah MOTEKAR sebagai social worker atau pekerja sosial mempunyai peranan strategis dalam penguatan institusi keluarga dalam rangka mencapai ketahanan keluarga, sehingga dapat meningkatkan kesejahteraan anak dan anggota keluarga yang lainnya bahkan dapat mengurangi permasalahan sosial yang terjadi (Fahrudin, 2016; Taylor \& Kvalsvig, 2008)

Data dari Badan Pusat Statistik menggambarkan bahwa Provinsi Jawa Barat merupakan provinsi dengan kepadatan penduduk paling tinggi di Indonesia. Jumlah penduduk Jawa Barat mencapai 48 juta jiwa atau 18,34 persen dari total populasi Indonesia (BPS, 2017). Kota Bandung merupakan salah satu wilayah terpadat di Jawa Barat dengan jumlah KK sebanyak 728.098 dengan total penduduknya mencapai 2.536.649 jiwa, hal ini tentu memunculkan tingkat kemajemukan dari masyarakatnya. Kemajemukan masyarakat mendorong berbagai ancaman dan kerentanan keluarga yang terjadi baik dari aspek fisik-ekonomi, sosial, maupun psikologis. Sehingga kebutuhan akan pendamping keluarga rentan tentu sangatlah dibutuhkan.

Berdasarkan data dari laporan kegiatan MOTEKAR tahun 2017 diperoleh informasi bahwa kondisi ketahanan keluarga di Provinsi Jawa Barat khususnya di Kota Bandung masih sangat menghawatirkan. Mayoritas permasalahan ketahanan keluarga berkaitan dengan masalah legalitas keluarga yaitu kepemilikian akta nikah, akta kelahiran, kartu keluarga, akta cerai hingga akta kematian sebanyak 12.087 kasus dan perceraian orang tua sebanyak 1.523 kasus. Selain itu diperoleh informasi mengenai permasalahan gizi anak sebanyak 58 kasus, permasalahan kesehatan ibu sebanyak 51 kasus, permasalahan anak putus sekolah di usia sekolah sebanyak 67 kasus, permasalahan anak disabilitas sebanyak 29 kasus, permasalahan pengasuhan anak bukan oleh orangtua kandung sebanyak 213 kasus dan permasalahan buruh imigran sebanyak 148 kasus. Dari data tersebut dapat terlihat bahwa kebutuhan terhadap MOTEKAR sebagai pendamping keluarga rentan di masyarakat adalah cukup tinggi.

Keluarga rentan jika harus berjuang sendiri, maka tidak akan mampu menghadapi berbagai ancaman yang datang bertubi-tubi pada keluarga, baik secara internal maupun eksternal. Oleh karena itu keluarga memerlukan stimulus dari luar yang membantu dan memfasilitasi keluarga dalam menghadapi berbagai gangguan keluarga. Stimulus yang dimaksud berupa motivasi-motivasi yang 
diberikan oleh orang lain yang berasal dari luar lingkungan keluarga.

Penelitian ini bertujuan untuk mengetahui :

Bagaimana peran dan fungsi MOTEKAR dalam memberdayakan keluarga rentan di Kota Bandung?”.

\section{METODE}

Penelitian ini dilakukan dengan menggunakan pendekatan kualitatif, metode deskriptif. Sasaran utama dari penelitian ini adalah MOTEKAR (Motivator Ketahanan Keluarga) yang ada di Kota Bandung, di Kecamatan Kiaracondong, Kelurahan Babakan Sari. Pemilihan sampel menggunakan Purposive Sample. Dipilih MOTEKAR yang ada di kelurahan Babakan Sari Kecamatan Kiaracondong Kota Bandung, dengan pertimbangan berdasarkan data yang ditemukan, terdapat kondisi kerentanan kelurga yang cukup tinggi ada di wilayah tersebut di bandingkan dengan wilayah lain di Kota Bandung. Adapun yang menjadi subjek penelitian adalah MOTEKAR, warga masyarakat dan aparat desa serta tokoh masyarakat. Waktu penelitian dilakukan selama empat bulan, dari Juli sampai November 2018.

\section{Tabel 1}

\section{Responden Penelitian}

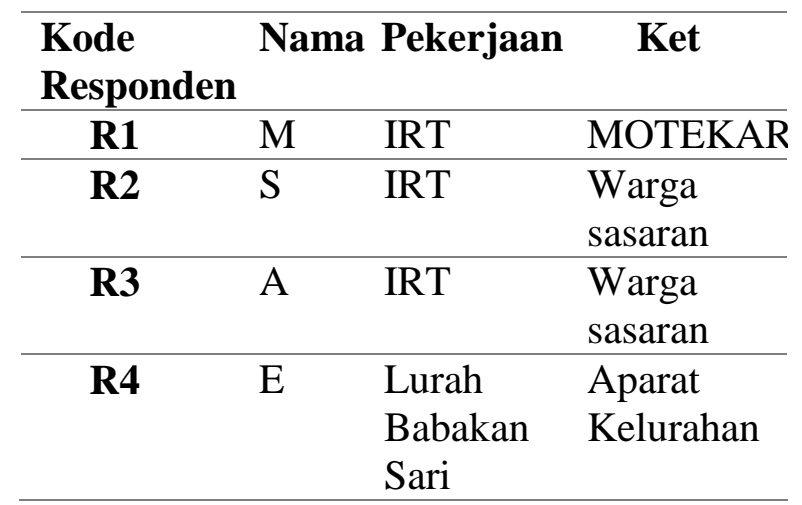

(Sumber: Peneliti, 2018).
Responden penelitian terdiri dari satu orang MOTEKAR yang bertugas di Kelurahan Babakan Sari, dua orang warga sasaran, dan satu orang aparat kelurahan. Teknik pengumpulan data, menggunakan observasi partisipatif, wawancara mendalam, dan studi dokumentasi.

Penggalian data difokuskan untuk mengeksplorasi data, terkait dengan aspek sebagai berikut:

1. Profil MOTEKAR

2. Kondisi wilayah binaan di Kelurahan babakan Sari

3. Indikator Ketahanan keluarga misi dari MOTEKAR

4. Peran MOTEKAR

- Mengidentifikasi

- Memotivasi

- Memediasi

- Mendidik

- Merencanakan

- Mengadvokasi

- Melaporkan

5. Fungsi MOTEKAR

- Motivator

- Fasilitator

- Inovator

- Dinamisator

\section{HASIL DAN PEMBAHASAN Profil MOTEKAR}

MOTEKAR merupakan singkatan dari motivator ketahanan keluarga yang dibentuk oleh melalui Peraturan Daerah Provinsi Jawa Barat Nomor 09 Tahun 2014 tentang Pembangunan Ketahanan Keluarga. Operasional MOTEKAR saat ini berada dibawah naungan Dinas Pemberdayaan Perempuan Perlindungan Anak dan Keluarga Berencana (DP3AKB) Provinsi Jawa Barat yang beralamat di Jln. Ir. H. Djuanda No.19, Dago, Coblong, Kota Bandung. 
Sasaran MOTEKAR adalah keluarga yang mengalami kerentanan dari berbagai aspek, misalnya aspek legalitas, aspek psikologi, aspek ekonomi, aspek pendidikan, aspek pendidikan dan sebagainya.

Tujuan MOTEKAR terbagi menjadi 2 tujuan yaitu tujuan umum dan tujuan khusus. Tujuan umum MOTEKAR adalah menyatupadukan pola pembinaan keluarga dan pemberdayaan perempuan yang berorientasi pada peningkatan kualitas hidup sejahtera lahir dan batin yang melibatkan partisipasi masyarakat dan lembaga terkait dalam semua tingkatan. Sedangkan tujuan khusus dalam kebijakan program yang memfasilitasi kader pemberdayaan masyarakat sebagai tenaga MOTEKAR dalam pembangunan kesejahteraan keluarga di Jawa Barat antara lain:

a. Meningkatkan kualitas hidup keluarga pra-sejahtera menjadikan keluarga sejahtera di Jawa Barat.

b. Mengoptimalkan peran perempuan dalam ketahanan keluarga, baik dari aspek pendidikan, sosial, ekonomi, budaya, dan politik agar memiliki keberdayaan diri dalam kehidupan keluarga dan masyarakat.

c. Mengembangkan pola-pola pengkaderan tenaga MOTEKAR sebagai kader pemberdayaan masyarakat di tingkat kelurahan/desa untuk memfasilitasi berbagai permasalahan dalam keluarga prasejahtera.

d. Mendorong sinergitas program MOTEKAR dengan program yang memiliki keterkaitan dengan ketahanan keluarga pada tingkatan pemerintahan provinsi dan kabupaten/kota di Jawa Barat.

e. Meningkatkan kapasitas pelaku masyarakat dan aparatur pemerintahan pada tingkatan desa/kelurahan di Jawa Barat.

MOTEKAR pada awal mula dibentuk beranggotakan 666 orang tersebar di 200 desa yang berada di 27 Kabupaten dan Kota di Jawa Barat. Seiring dengan perkembangannya MOTEKAR mengalami penurunan dari kuantitas di beberapa wilayah, hal ini dikarenakan berbagai faktor diantaranya yaitu tingkat usia MOTEKAR yang mendekati usia pensiun, wafat, dan mengundurkan diri.

Dalam perkembangan dari sisi kuantitas sejak tahun 2015 sampai 2018, MOTEKAR yang tersebar pada awalnya di 200 desa. Saat ini MOTEKAR ada di 312 desa di Jawa Barat. Perubahan lain yang terjadi, pada awalnya penempatan MOTEKAR ini sebanyak lima orang perdesa, namun dikarenakan adanya permintaan dari desa/kota dan kabupaten untuk menambah wilayah jangkauan MOTEKAR, maka dikembangkanlah wilayah jangkauan MOTEKAR sehingga setiap desa memiliki dua atau tiga orang MOTEKAR di desa/kelurahannya tergantung kebutuhan dari daerah masing-masing.

Berikut adalah penempatan MOTEKAR yang tersebar di 312 desa di Jawa Barat dengan jumlah anggota aktif sebanyak 617 orang yang tersebar di 27 kabupaten dan kota di Jawa Barat dengan rincian dalam tabel (4.1.1.) dibawah ini:

\section{Tabel 2}



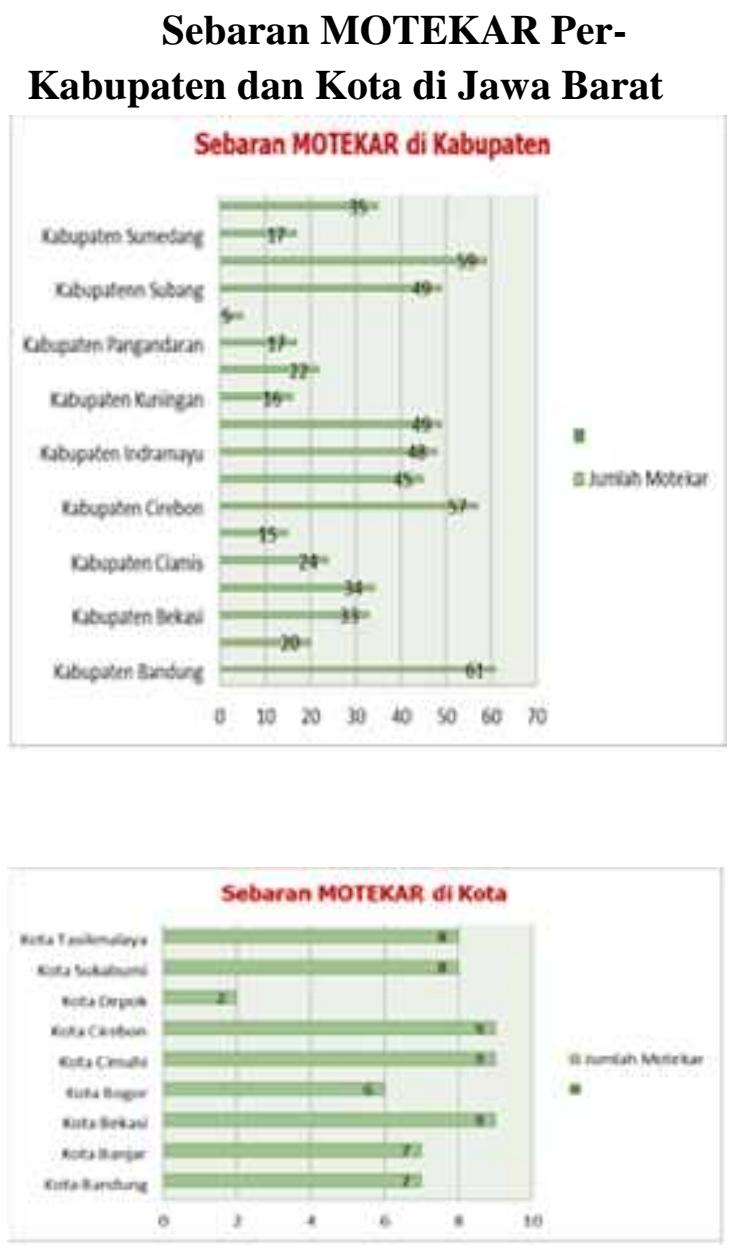

(Sumber: Peneliti, 2018).

Berdasarkan data tersebut, semua wilayah kabupaten dan kota di Jawa Barat memiliki persebaran MOTEKAR sebagai perwakilan, namun hanya desa/kelurahan tertentu saja yang memiliki MOTEKAR di desanya. Hal ini sejalan dengan informasi yang diperoleh dari wawancara dengan pihak pengelola bahwa penempatan MOTEKAR hanya ditujukan bagi desa atau kelurahan yang memiliki tingkat keluarga rentan dan keluarga prasejahtera yang tinggi sehingga penempatannya hanya ada di 312 desa di Jawa Barat.

\section{Kondisi Wilayah Kelurahan Babakan Sari Kecamatan Kiaracondong Kota Bandung}

Kelurahan Babakansari merupakan salah satu kelurahan di Kecamatan Kiaracondong Kota Bandung. Luas wilayah Kelurahan Babakansari mencapai 88,09 Hektar, dengan jumlah kepala keluarga mencapai 4.915 KK. Kelurahan Babakansari merupakan salah satu wilayah padat penduduk di Kecamatan Kiaracondong dengan jumlah rukun warga sebanyak $18 \mathrm{RW}$, dan rukun tetangga sebanyak 148 RT dan jumlah penduduknya mencapai 14.212 jiwa.

Berdasarkan letak geografis, Kelurahan Babakansari tidak memiliki banyak sumber daya alam yang dapat diandalkan sehingga mayoritas penduduknya merupakan pekerja lepas sehingga tidak ada jaminan yang memadai mengenai pendapatan keluarga. Hal inilah yang menyebabkan banyaknya kerentanan yang terjadi di Kelurahan Babakansari dalam segi sosial maupun psikologis. Berdasarkan hasil studi dokumentasi (Februari 2018) tercatat ada 526 orang yang tidak memiliki legalitas, 343 orang mengalami masalah ketahanan ekonomi, 260 orang mengalami masalah sosial-psikologis, dan 689 orang mengalami masalah ketahanan fisik.

Penanganan permasalahan ketahanan keluarga oleh MOTEKAR di wilayah Kelurahan Babakansari didukung beberapa perangkat wilayah diantaranya yaitu PLI-PPA (Pusat Layanan Informasi Perlindungan Perempuan dan Anak), PATBM 
(Perlindungan Anak Terpadu Berbasis Masyarakat), RT dan RW setempat, Tokoh Agama, Tokoh Masyarakat. Selain itu dalam melaksanakan peran dan fungsinya di masyarakat MOTEKAR didukung oleh berbagai program yang turut pendukung upaya peningkatan ketahanan keluarga di wilayah Kelurahan Babakansari seperti PKH (Program Keluarga Harapan), RBM (Rehabilitasi Berbasis Masyarakat), POSYANDU (Pos Pelayanan Terpadu) dan KLA (Kelurahan Layak Anak). Hal ini menjadi salah satu daya dukung MOTEKAR dalam menangani masalah ketahanan keluarga di Kelurahan Babakansari sehingga MOTEKAR tidak bekerja sendirian melainkan melibatkan berbagai sumberdaya dan mitra yang ada.

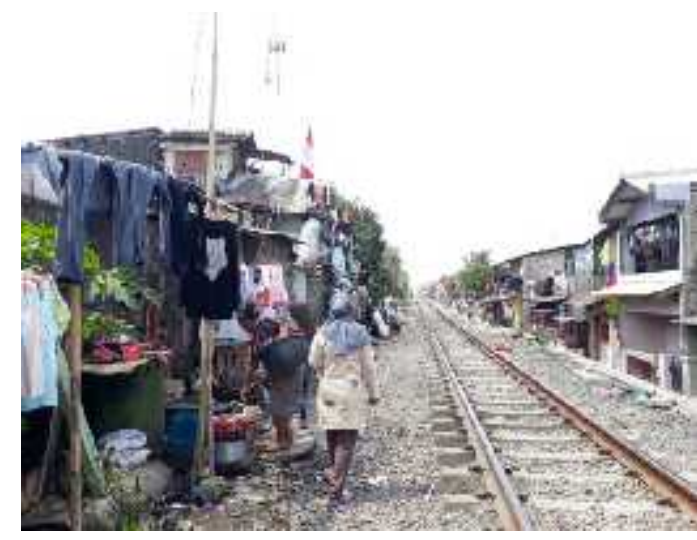

Gambar 1

Kondisi Empiris Wilayah Binaan

MOTEKAR di Kelurahan Babakansari

(Sumber: Dokumentasi Penelitian, 2018).

\section{Indikator Ketahanan Keluarga Misi MOTEKAR}

\section{MOTEKAR (Motivator}

Ketahanan Keluarga) yang menjadi tenaga di masyarakat dibawah koordinasi DP3AKB, memiliki misi dalam membangun ketahanan keluarga. Adapun yang menjadi perhatian yang ditugaskan dalam pelaporan terkait indikator ketahanan keluarga, meliputi:

Tabel 3. Dimensi Ketahanan Keluarga pelaporan ke DP3AKB

\section{Dimensi Indikator}

\begin{tabular}{|c|c|}
\hline $\begin{array}{l}\text { Legalitas } \\
\text { dan } \\
\text { Keutuhan } \\
\text { Keluarga }\end{array}$ & $\begin{array}{l}\text { - kepemilikan buku nikah, } \\
\text { - kepemilikan kartu keluarga, } \\
\text { - kepemilikan akte kelahiran } \\
\text { anak, } \\
\text { - kepemilikan akte cerai } \\
\text { - kepemilikan surat kematian }\end{array}$ \\
\hline $\begin{array}{c}\text { Ketahanan } \\
\text { Fisik }\end{array}$ & $\begin{array}{l}\text { - masalah-masalah kecukupan } \\
\text { gizi keluarga (anak dan } \\
\text { balita) } \\
\text { - kesehatan keluarga (balita, } \\
\text { ibu, anak, disabilitas, lansia) } \\
\text { - rumah yang ditempati oleh } \\
\text { keluarga. (pola hidup bersih } \\
\text { dan sehat, pelayanan lansia, } \\
\text { rumah tidak layak huni) }\end{array}$ \\
\hline $\begin{array}{c}\text { Ketahanan } \\
\text { Ekonomi }\end{array}$ & $\begin{array}{l}\text { - pendapatan keluarga } \\
\text { (ekonomi keluarga) } \\
\text { - pembiayaan pendidikan anak } \\
\text { (putus sekolah, anak jalanan) } \\
\text { - tempat tinggal keluarga } \\
\text { hingga jaminan pendapatan } \\
\text { keluarga. }\end{array}$ \\
\hline $\begin{array}{l}\text { Ketahanan } \\
\text { Sosial } \\
\text { Psikologis }\end{array}$ & $\begin{array}{l}\text { - keharmonisan } \\
\text { keluarga. (buruh migran, } \\
\text { kekerasan pada anak, } \\
\text { kekerasan dalam rumah } \\
\text { tangga, penelantaran anak, } \\
\text { pola asuh yang tidak tepat, } \\
\text { pendampingan anak yang } \\
\text { terkena kasus pornografi) }\end{array}$ \\
\hline $\begin{array}{l}\text { Ketahanan } \\
\text { Sosial } \\
\text { Budaya }\end{array}$ & $\begin{array}{l}\text { - masalah-masalah mengenai } \\
\text { kepedulian sosial, } \\
\text { - keeratan sosial, dan } \\
\text { - ketaatan beragama }\end{array}$ \\
\hline
\end{tabular}




\section{Peran MOTEKAR}

MOTEKAR dalam menjalankan tugasnya, dituntut untuk melaporkan beberapa kondisi ketahanan keluarga di wilayah binaan masing masing. Indikator ketahanan keluarga yang dilaporkan, sesuai format yang telah disiapkan oleh DP3AKB tingkat Propinsi Jawa Barat dan melakukan koordinasi pelaporan dengan DP3APM di Kota Bandung.

Berikut adalah tugas yang dilaksanakan MOTEKAR di lapangan terkait dengan perannya:

a. Mengidentifikasi

MOTEKAR melakukan pendataan/ identifikasi wilayah melalui 2 cara yaitu 1) melalui door to door ke rumah-rumah warga sasaran dan 2) Berkoordinasi dengan RT dan RW setempat.

MOTEKAR melakukan identifikasi dengan menggunakan format-format yang disediakan oleh pihak pengelola. Selanjutnya setelah melakukan pendataan, warga sasaran di kelompokkan ke dalam 2 kelompok yaitu keluarga rentan dan keluarga tidak rentan.

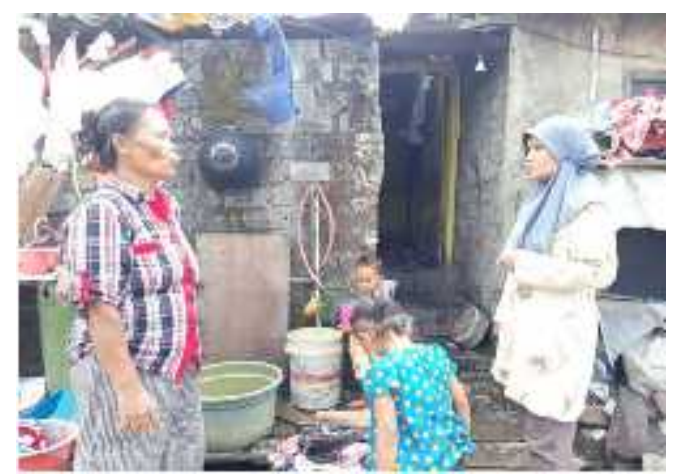

Gambar 2. Aktivitas door to door

MOTEKAR melakukan identifikasi dan pengumpulan data
MOTEKAR dalam kesempatan melakukan pendataan sekaligus juga memberikan motivasi apabila menemukan warga yang membutuhkan khususnya di keluarga rentan. Berbagai kondisi yang dihadapi sangat beragam tergantung kebutuhan warga sasaran, mulai dari masalah legalitas keluarga, pola asuh, kesehatan keluarga, hingga keharmonisan keluarga.

\section{c. Memediasi}

Mediasi yang dilakukan oleh MOTEKAR akan melibatkan pengurus setempat seperti RT, RW, kader-kader di masyarakat hingga tokoh-tokoh lainnya yang ada dilingkungan setempat. Mediasi yang dilakukan MOTEKAR dengan melakukan pendampingan dalam menghadapi masalah sekaligus pemberian motivasi kepada warga sasarannya. Beberapa permasalahan yang dihadapi misalnya masalah kekerasan pada anak, penelantaran anak, kekerasan dalam rumah tangga hingga menyebabkan luka serius, atau masalah penelantaran anak oleh orangtuanya maka MOTEKAR melakukan mediasi atau menjembatani pelaku dan korban ke DP3APM (Kota Bandung) dan P2TP2A Propinsi Jawa Barat.

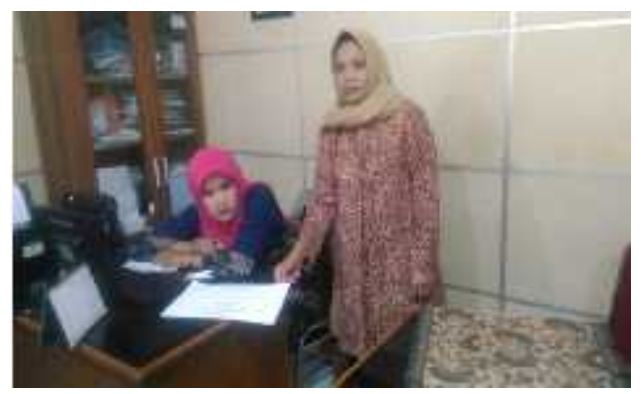

Gambar 3. MOTEKAR dan aparat kelurahan (Ibu Lurah Babakan Sari)

b. Memotivasi 
membahas kasus dan memediasi warga yang bermasalahan

d. Mendidik

Mendidik yang dilakukan oleh MOTEKAR, bukan mendidik secara formal tetapi lebih pada perubahan pola pikir atau pemahaman dan kesadaran warga sasaran khususnya mengenai ketahanan keluarga sehingga warga sasaran mampu memberdayakan dirinya dan keluarganya. Kesempatan mendidik dilakukan MOTEKAR dalam berbagai kesempatan, karena memang MOTEKAR di babakan sari, dipilih oleh Ibu Lurah, merupakan kader PKK yang aktif di wilayahnya. Sehingga peran MOTEKAR akan melekat dalam setiap aktivitas hariannya.

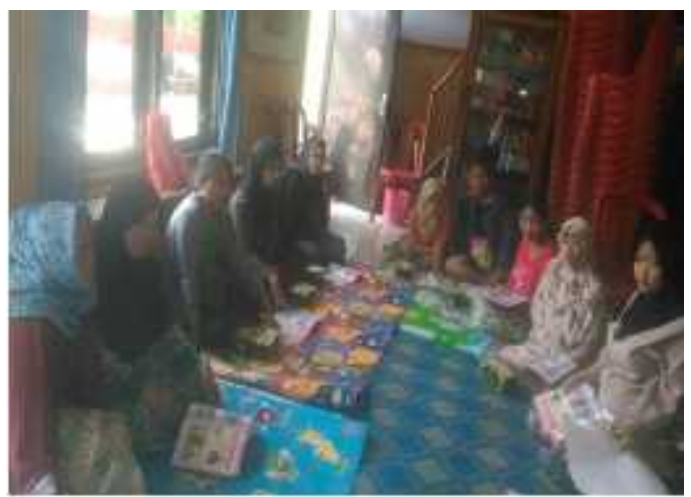

Gambar 4. Aktivitas mendidik yang dilakukan MOTEKAR di babakan sari

e. Merencanakan Solusi

MOTEKAR dalam merencanakan solusi melibatkan RT, RW, kader-kader, tokoh agama, tokoh pendidikan, tokoh masyarakat setempat tergantung besar kecilnya masalah yang dihadapi oleh warga sasaran. Perencanaan solusi terhadap masalah yang bisa ditangani sendiri oleh MOTEKAR, dilakukan Bersama warga sasaran yang bersangkutan. MOTEKAR sebagai agen yang membantu warga menemukan sendiri solusi dari permasalahannya.

f. Mengadvokasi

Disampaikan oleh pengelola, bahwa advokasi hampir tidak pernah dilakukan oleh MOTEKAR sebab masalahmasalah yang muncul biasanya mengenai legalitas keluarga, namun jika ada masalah mengenai kekerasan pada keluarga biasanya dapat diselesaikan secara kekeluargaan. Advokasi yang dilakukan oleh MOTEKAR hanya sebatas pelaporan berupa rujukan kepada DP3APM dan P2TP2A bagi kasus-kasus yang tidak bisa diadvokasi oleh MOTEKAR. (diungkapkan oleh MOTEKAR)

\section{g. Melaporkan}

Pelaporan dilakukan MOTEKAR rutin setiap 1 bulan 1x dengan menggunakan format yang diberikan oleh pengelola. Pelaporan dibuat oleh MOTEKAR setiap bulannya yang ditujukan sebagai hasil kinerja selama 1 bulan. Format laporan yang dibuat oleh MOTEKAR berisikan dimensi-dimensi ketahanan keluarga mulai dari dimensi legalitas dan keutuhan keluarga, dimensi ketahanan fisik, dimensi ketahanan ekonomi, dimensi ketahanan sosial-psikologis, dan dimensi ketahanan sosial-budaya.

\section{Fungsi MOTEKAR}

Beberapa fungsi MOTEKAR yang melekat dalam berbagai aktivitas dan perannya, diantaranya adalah sebagai Motivator, Fasilitator, Inovator, dan Dinamisator. 
Tabel 4. Fungsi MOTEKAR dan Aktivitasnya

\begin{tabular}{|c|c|}
\hline Fungsi & Aktivitas \\
\hline Motivator & $\begin{array}{l}\text { MOTEKAR menjadi } \\
\text { pendengar yang baik untuk } \\
\text { warga sasaran dalam } \\
\text { mencurahkan keluh } \\
\text { kesahnya sehingga warga } \\
\text { sasaran tidak merasa } \\
\text { canggung untuk berbicara } \\
\text { kepada MOTEKAR. Selain } \\
\text { itu MOTEKAR selalu } \\
\text { memberikan motivasi, dan } \\
\text { tidak pernah menyalahkan } \\
\text { warga sasaran. }\end{array}$ \\
\hline Fasilitator & $\begin{array}{l}\text { MOTEKAR sering diminta } \\
\text { menjadi pihak ketiga dalam } \\
\text { menjembatani warga } \\
\text { sasaran dengan } \\
\text { menawarkan alternatif } \\
\text { solusi. MOTEKAR pun } \\
\text { melakukan fasilitasi kepada } \\
\text { pihak lain untuk dapat } \\
\text { menyelesaikan masalah }\end{array}$ \\
\hline Inovator & $\begin{array}{l}\text { Inovasi dilakukan } \\
\text { MOTEKAR dan } \\
\text { masyarakat untuk } \\
\text { menjawab permasalahan. } \\
\text { Salah satu inovasi di RW } \\
\text { yaitu mengadakan iuran } \\
\text { wajib daerah. Iuran wajib } \\
\text { daerah (IWD) ini } \\
\text { merupakan iuran wajib } \\
\text { yang ditetapkan oleh } \\
\text { pengurus wilayah setempat } \\
\text { dan MOTEKAR yang } \\
\text { ditarik setiap bulan, yang } \\
\text { diperuntukkan bagi gaji } \\
\text { hansip, uang kebersihan, } \\
\text { gaji guru ngaji, pemberian } \\
\text { makanan tambahan bagi } \\
\text { anak-anak yang mengalami } \\
\text { gizi kurang, jenguk orang } \\
\text { sakit dan uang pengurusan } \\
\text { jenazah. }\end{array}$ \\
\hline $\mathrm{am}$ & $\begin{array}{l}\text { MOTEKAR dan pengurus } \\
\text { wilayah setempat selalu }\end{array}$ \\
\hline
\end{tabular}

melibatkan warga sasaran dalam kegiatan-kegiatan masyarakat terutama yang berkaitan dengan keeratan sosial, kepedulian sosial dan ketaatan beragama kepentingan umum, sehingga keluarga rentan dapat ikut berkontribusi di lingkungannya

MOTEKAR yang ada di kelurahan Babakan Sari, dipilih dari kader PKK yang aktif di berbagai kegiatan di kelurahan. Sehingga sebagai MOTEKAR, peran dan fungsinya dapat dilakukan seiring dengan aktivitas hariannya sebagai penggiat di masyarakat, bahkan menjadi lebih bermakna karena materi pembangunan ketahanan keluarga yang dibekalkan dari pelatihan kepada MOTEKAR secara rutin.

MOTEKAR lebih berorientasi pada upaya memotivasi dan memfasilitasi keluarga rentan. Motivasi merupakan unsur penting dalam diri manusia yang berperan mewujudkan keberhasilan dalam usaha atau pekerjaan manusia. Handoko dalam (Simbolon, 2017, hlm. 27) mengungkapkan bahwa motivasi merupakan suatu tenaga atau faktor yang terdapat didalam diri manusia yang menimbulkan, mengarahkan, dan mengorganisasikan tingkah lakunya. Setiap individu dalam melakukan berbagai aktivitasnya sangat dipengaruhi oleh adanya dorongan atau yang dikenal dengan istilah motivasi. Dorongan tersebut dapat berasal dari dalam diri seseorang maupun dari luar diri seseorang. 
Keluarga jika harus berjuang sendiri dalam menghadapi berbagai ancaman keluarga baik secara internal maupun eksternal, tidak akan mampu. Oleh karena itu keluarga memerlukan dampingan dan stimulan dari luar yang akan membantu keluarga dalam menghadapi permasalahan. Stimulan tersebut adalah berupa motivasimotivasi yang diberikan pada keluarga rentan diwilayah binaan MOTEKAR. Sehingga peran MOTEKAR bagi keluarga rentan untuk membangun ketahanan keluarga sangatlah dibutuhkan. Berbagai kondisi kerentanan keluarga baik dari aspek fisik, psikologis, dan sosial memerlukan dukungan pihak luar, dalam hal ini pemerintah melalui agen pemberdaya keluarga, diantaranya adalah MOTEKAR.

\section{KESIMPULAN} MOTEKAR

(Motivator

Ketahanan Keluarga) dalam menjalankan peran dan fungsinya memberdayakan keluarga bertujuan untuk membangun ketahanan keluarga di masyarakat. Keluarga yang rentan akibat keterbatasannya dalam menyelesaikan permasalahan baik karena kondisi ekonomi, psikologis dan social membutuhkan dampingan yang memadai. MOTEKAR yang hadir bersama-sama dengan aparat di kelurahan dan RW RT serta tokoh, menjadikan lingkungan yang saling menguatkan akan terbangun.

Keterbatasan dan permasalahan MOTEKAR dalam menjalankan peran dan fungsinya, selain faktor internal, juga akan lebih besar akibat faktor eksternal, khususnya berkaitan dengan masalah koordinasi antar lembagalembaga yang berkepentingan upaya mediasi dan advokasi dalam masalah warga.

Keterbatasan lain terkait dengan faktor internal yang berkaitan dengan kemampuan setiap MOTEKAR dalam melakukan aktivitas pemberdayaan. Pengalaman dan keilmuan yang harus terus ditingkatkan untuk bisa menjadi konselor dan pemberdaya masyarakat menjadi kendala utama MOTEKAR. Perlu ada penelitian lebih lanjut terkait dengan kaitan antara pengalaman dan tingkat pendidikan MOTEKAR dengan kompetensi mereka dalam memberdayakan masyarakat. Selain itu perlu digali, terkait peran dan fungsi MOTEKAR, kompetensi apa yang menjadi prasyarat utama seorang pemberdaya keluarga sehingga perlu menjadi bahan masukan dalam pengembangan sumber daya tenaga penggerak dan penggiat masyarakat dalam membangun ketahanan keluarga.

\section{DAFTAR PUSTAKA}

[1] Alix, E. K., \& Lautz, H. R. (1973). Socioeconomic Status and Low Occupational Aspirations: Resignation as an Orientational Variable. Social Science Quarterly, 54, 596-607.

[2] Blum, A. A. (1964). Social structure, social class and participation in primary relationships. In A. B. Shostak \& N. Gomberg (Eds.), Bluecollar world: studies of the American worker, pp. 195-207. Englewood Cliffs, NJ: Prentice-Hall.

[3] BP3AKB. (2014). Pedoman Umum Program Motivator Ketahanan 
Keluarga (MOTEKAR) di Jawa Barat. Bandung: BP3AKB.

[4]

Motivator Ketahanan Keluarga (MOTEKAR). Bandung: BP3AKB.

[5] Dorothy S. Becvar. (2013). Handbook of Family Resilience. New York: Springer Science+Business Media.

[6] Fahrudin, A. (2016). Ketahanan Institusi Keluarga dan Kesejahteraaan Anak. Journal ResearchGate University Malaysia Sabah (UMS).

[7] Gitmez, et al. (1995). A Typology of The Urban Poor In Turkey. Journal of urban affairs, Volume 17, Number 4, pages 413-422.

[8] Langer, M. (1963). Life, Stress and Mental Health. New York: Free Press.

[9] Matthews, D. R. (1954). Social Background of Political Decision Makers. New York: Random House.

[10] Peraturan Daerah Provinsi Jawa Barat Nomor 9 Tahun 2014 Tentang Penyelenggaraan Pembangunan Ketahanan Keluarga.

[11] Peraturan Menteri Pemberdayaan Perempuan Dan Perlindungan Anak Nomor 6 Tahun 2013 Tentang Pelaksanaan Pembangunan Ketahanan Keluarga.

[12] Simbolon, G. (2017). Pengaruh Kompetensi Instruktur dan Motivasi Berprestasi Terhadap Hasil Pelatihan Otomotif (Studi Pada Pelatihan Otomotif di Pusat Pelatihan Kerja Daerah Provinsi DKI Jakarta). TESIS: Pendidikan Luar Sekolah Sekolah Pasca Sarjana Universitas Pendidikan Indonesia. Tidak Diterbitkan.

[13] Sunarti, E. (2014). Modul Ketahanan Keluarga Bagi MOTEKAR (Motivator Ketahanan Keluarga di Jawa Barat). Bandung: BP3AKB.
[14] (2017). Modul Ringkasan Materi Pelatihan Diagnostik Ketahanan Keluarga. Bogor: Penggiat Keluarga GiGa Indonesia.

[15] Taylor, M., \& Kvalsvig, J. D. (2008). Scaling up support for children inHIV-affected families by involving early childhood development workers: Community views from KwaZu-lu-Natal, South Africa. Jurnal of Development Southern Africa, 25,61.http://dx.doi.org/10.1080/03 768350701836202

[16] Undang-Undang Nomor 52 Tahun 2009 Tentang Perkembangan Kependudukan Dan Pembangunan Keluarga.

[17] Wright, C. R., \& Hyman, H. H. (1958). Voluntary association membership of American adults: evidence from national sample surveys. American Sociological Review, 23,284-294. 